\title{
Two new nematodes, Paraseuratoides ophisterni gen. et sp. n. (Quimperiidae) and Philometra ophisterni sp. n. (Philometridae), from the swamp-eel Ophisternon aenigmaticum in Mexico
}

\author{
František Moravec $^{1}$, Guillermo Salgado-Maldonado ${ }^{2}$ and Rogelio Aguilar-Aguilar ${ }^{2}$ \\ ${ }^{1}$ Institute of Parasitology, Academy of Sciences of the Czech Republic, Branišovská 31, 37005 České Budějovice, Czech \\ Republic; \\ ${ }^{2}$ Institute of Biology, National Autonomous University of Mexico, A.P. 70-153, 04510 Mexico, D.F., Mexico
}

Key words: Nematoda, parasites, Paraseuratoides, Philometra, fish, Ophisternon, Mexico

\begin{abstract}
Two new nematodes, Paraseuratoides ophisterni gen. et sp. n. (Seuratoidea: Quimperiidae) and Philometra ophisterni sp. n. (Dracunculoidea: Philometridae) are described based on specimens recovered from the intestine and mesentery, respectively, of the swamp-eel Ophisternon aenigmaticum Rosen et Greenwood (Synbranchiformes: Synbranchidae) from a canal of the Papaloapan River in Tlacotalpan, State of Veracruz, Mexico. The genus Paraseuratoides is most similar to Paraseuratum Johnston et Mawson, 1940, differing from it mainly in the absence of a bulbous inflation on the anterior end of the oesophagus and in the structure of the mouth (presence of 6 spines in addition to 6 oesophageal teeth). Neoquimperia Wang, Zhao, Wang et Zhang, 1979 and Wuinema Yu et Wang, 1992 are synonymised with Ezonema Boyce, 1971 and Paragendria Baylis, 1939, respectively, and Haplonema hamulatum Moulton, 1931 is considered a junior synonym of Ichthyobronema conoura Gnedina et Savina, 1930. Philometra ophisterni (only females) is mainly characterised by minute cephalic papillae, a greatly developed anterior oesophageal bulb separated from the cylindrical part of the oesophagus, anterior extension of the oesophageal gland anterior to the nerve ring, and by the character of large caudal projections. This is the first Philometra species recorded from inland fishes in Mexico.
\end{abstract}

Swamp-eels of the genus Ophisternon McClelland (Synbranchiformes: Synbranchidae) are represented in Mexico by two species, $O$. aenigmaticum Rosen et Greenwood, distributed in Cuba, Belize, Honduras, Guatemala and on both coasts of Mexico, and $O$. infernale (Hubbs), a rare endemic species in caves and cenotes (=sinkholes) of the Yucatán Peninsula in Mexico (Espinosa Pérez et al. 1993). Until recently, there were no data on the helminth parasites of these fishes. Because of its rarity, the blind eel, O. infernale, has not been examined for parasites to date, whereas there are only a few published records of the helminth parasites of $O$. aenigmaticum from Veracruz (Catemaco Lake) and Yucatán in Mexico (Moravec et al. 2000, Scholz et al. 2001a, b).

In April and May 2001, during investigations into the metazoan parasites of fishes of the Papaloapan River in Tlacotalpan, Veracruz, several specimens of $O$. aenigmaticum were examined. In addition to some other helminth parasites recorded from this fish, two species of nematodes new to science were found. These are described below.

\section{MATERIALS AND METHODS}

In April and May 2001, nine specimens of the swamp-eel Ophisternon aenigmaticum Rosen et Greenwood (total body length $26-57 \mathrm{~cm}$ ) were examined; these were caught using eel traps by a local fisherman. After washing in physiological saline, the nematodes were fixed in hot $4 \%$ formaldehyde in saline. For examination, they were cleared in glycerine. Drawings were made with the aid of a Zeiss microscope drawing attachment. For scanning electron microscopy (SEM), body fragments of three females of Philometra ophisterni and the anterior end of one female (allotype) of Paraseuratoides ophisterni were postfixed in 1\% osmium tetroxide, dehydrated through a graded ethanol series, critically point dried, and sputter-coated with gold. They were examined with a JEOL JSM-6300 scanning electron microscope at an accelerating voltage of $15 \mathrm{kV}$. Measurements are in $\mathrm{mm}$ unless otherwise stated. Type specimens have been deposited in the National Helminthological Collection, National Autonomous University of Mexico (UNAM), in Mexico City and in the helminthological collection of the Institute of Parasitology, Academy of Sciences of the Czech Republic (ASCR), in České Budějovice.

\section{RESULTS}

Family Qu i m p e ri id a e Gendre, 1928

\section{Paraseuratoides gen. n.}

Diagnosis: Quimperiidae. Cephalic end truncated; mouth without lips, provided with six small spines. Four large submedian cephalic papillae present. Buccal cavity armed with six oesophageal teeth. Lateral alae absent. Small deirids and excretory pore at oesophagus 
level. Oesophagus long, undivided, without inflation at anterior end, its posterior somewhat greater in diameter than anterior. Male: caudal alae and precloacal sucker absent, oblique muscle bands in precloacal region present. Spicules equal. Short gubernaculum present. Female: vulva postequatorial, uterus opposed. Eggs non-embryonated in uteri. Intestinal parasites of freshwater fishes.

Type and the only species: Paraseuratoides ophisterni $\mathrm{sp} . \mathrm{n}$.

E t y m o lo g y : The new generic name is derived from that of the related genus Paraseuratum.

\section{Paraseuratoides ophisterni sp. n.}

Figs. 1, 2

Description: Medium sized, whitish nematodes with thin, finely transversely striated cuticle. Cephalic end truncated, without lips. Buccal capsule absent. Oral aperture approximately pentagonal, surrounded by broad circumoral ring of somewhat elevated tissue, containing four large submedian cephalic papillae, two subdorsal and two subventral, and pair of small lateral amphids. Lateral fields of cephalic end somewhat elevated. Oral opening provided with six short spines, two dorsal, two lateral and two subventral, protruding out into buccal cavity. Bottom of buccal cavity with six large, conical, anteriorly directed oesophageal teeth. Lateral alae absent. Deirids small, inconspicuous, situated slightly posterior to mid-length of oesophagus. Oesophagus rather long, muscular throughout, somewhat broader at its posterior part, opening into intestine through distinct valve; pharyngeal part of oesophagus practically not separated, only slightly outlined by small transverse extension of oesophageal lumen. Nerve ring situated approximately at border of first and second fourths of length of oesophagus, excretory pore in middle between deirids and posterior end of oesophagus. Tail of both sexes conical, with distinct slender, terminal cuticular spike.

Male (1 specimen, holotype): Length of body 9.34, maximum width 0.367 . Height of mouth region 0.015 . Overall length of oesophagus 1.55 (17\% of whole body length), its slightly outlined pharyngeal part 0.054 long; width of oesophagus anterior to nerve ring 0.057 , maximum width at its posterior part 0.096. Nerve ring, deirids and excretory pore $0.381,0.925$ and 1.27 , respectively, from anterior extremity. Anterior end of testis some distance posterior to end of oesophagus. Cloacal lips slightly elevated. Preanal papillae: 3 pairs of subventral papillae and 1 large median unpaired papilla present; adanal papillae: 1 subventral pair; postanal papillae: 5 pairs, of which 4 pairs being subventral, forming two couples (one close to cloacal aperture and one near tail end), and 1 pair lateral, situated between adanal and first postanal subventral pairs; papillae of last two pairs of postanals somewhat asymmetrical. Caudal alae and precloacal sucker absent. Ventral precloacal surface with 12 weakly developed oblique muscle bands. Spicules equal, curved, 0.555 long, each provided with two longitudinal, heavily sclerotised rod-like supports not reaching anteriorly to anterior end of spicule and broad ala extending along whole spicule length; proximal end of spicule blunt, distal end narrowed, pointed, with membranous cover. Gubernaculum well developed, V-shaped in ventral view, 0.120 long. Tail bent ventrally, 0.544 long; length of terminal cuticular spike 0.024 .

Female (1 specimen, allotype): Length of body 11.22 , maximum width 0.422 . Height of mouth region 0.018 . Overall length of oesophagus $1.90(17 \%$ of whole body length), its slightly outlined pharyngeal part 0.075 ; width of oesophagus anterior to nerve ring 0.081 , maximum width at its posterior part 0.125 . Nerve ring, deirids and excretory pore $0.435,1.09$ and 1.40 , respectively, from anterior extremity. Vulva with slightly elevated lips, situated in posterior half of body, 9.34 from anterior extremity (at $76 \%$ of body length). Muscular vagina directed anteriorly from vulva. Uterus didelphic, amphidelphic, containing about 30 eggs in both pre- and post-vulvar regions. Anterior ovary (forming coil) situated ventrally in anterior part of body, followed by tubular oviduct going anteriorly to certain distance posterior to oesophagus, then returning back almost to level of posterior ovary, again curving anteriorly and gradually turning to uterus; posterior ovary (forming coil) situated dorsally short distance anterior to end of intestine, its oviduct running anteriorly to almost same level as that of anterior ovary, then returning back, and gradually turning to uterus; anterior coils of both oviducts at almost same level at certain distance posterior to oesophagus. Eggs oval, thin-walled, unembryonated, measuring 0.042-0.045 $\times$ $0.030-0.033(\mathrm{n}=10)$. Tail $0.612 \mathrm{long}$; length of terminal cuticular spike 0.024 .

T y p e h o s t: Swamp-eel, Ophisternon aenigmaticum Rosen et Greenwood, 1976 (total body length $44 \mathrm{~cm}$ ).

$\mathrm{S}$ i t e : Intestine.

T y p e 1 o c a 1 i t y : Canal near the Papaloapan River at Tlacotalpan $\left(18^{\circ} 36^{\prime} \mathrm{N}, \quad 95^{\circ} 39^{\prime} \mathrm{W}\right)$, Veracruz, Mexico (collecting date: 1 May 2001).

Prevalence and intensity: 11\% (1 fish infected/ 9 fish examined); 2 nematodes.

De position of speci mens: Holotype and allotype in the Institute of Biology, National Autonomous University of Mexico (UNAM), Mexico City (Cat. Nos. CNHE 4290 and 4291).

E $\mathrm{t} y \mathrm{~m} \mathrm{o} \log \mathrm{y}$ : The specific name relates to the generic name of the host, i.e., Ophisternon.

Comments: The general morphology of this species, particularly the structure of the cephalic end, oesophagus, male caudal end, and reproductive organs, shows clearly that it belongs to the seuratoid family Quimperiidae Gendre, 1928. According to Chabaud (1978), this family includes 12 valid genera, of which Omeia Hsü, 1933, characterised by the presence of a 
A



$5]$
D

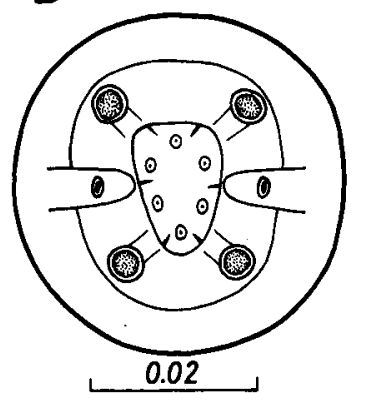

$\mathbf{E}$

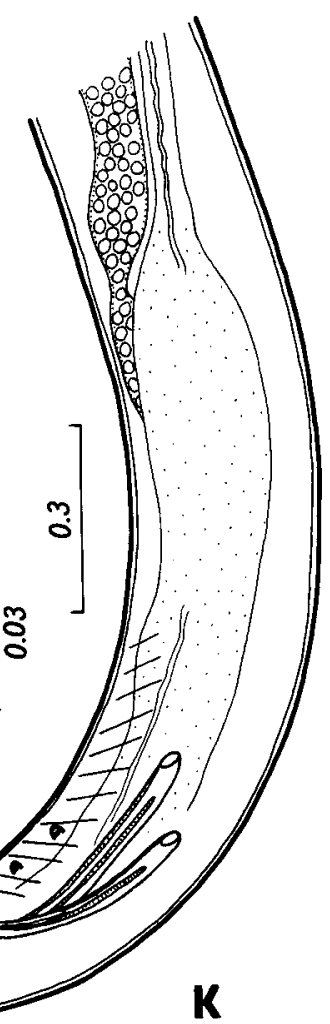

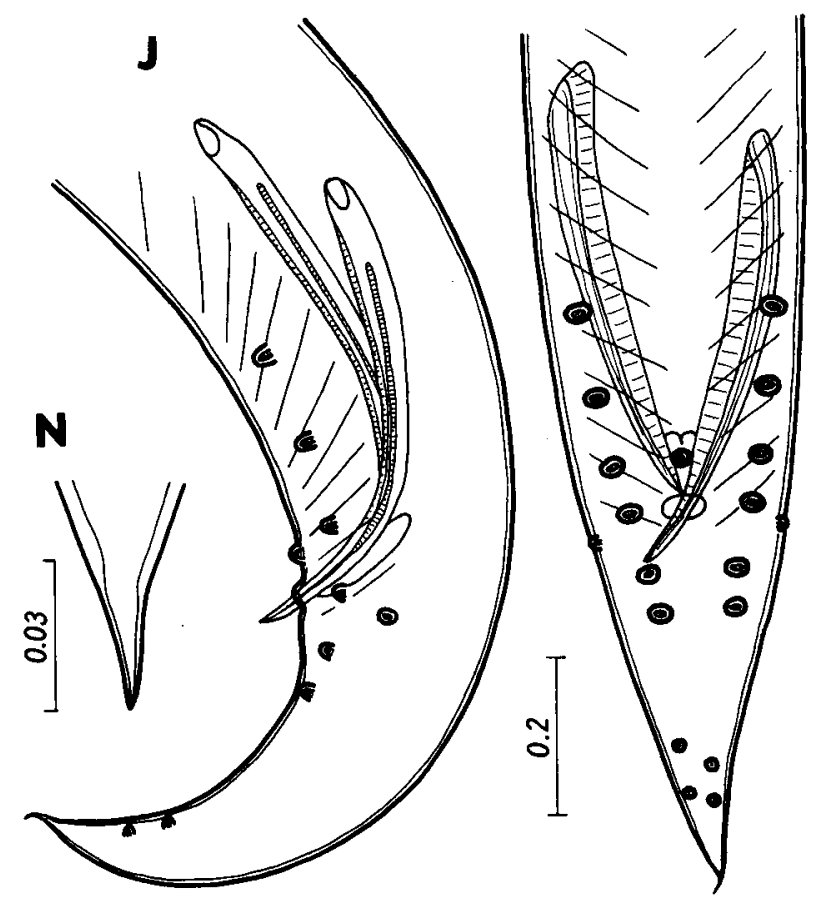

Fig. 1. Paraseuratoides ophisterni gen. et sp. n. $\mathbf{A}$ - anterior end of female, lateral view; $\mathbf{B}$ - anterior end of male, dorsoventral view; C, D - cephalic end, lateral and apical views; $\mathbf{E}$ - posterior end of male, lateral view; $\mathbf{F}$ - deirid; $\mathbf{G}$ - gubernaculum, ventral view; $\mathbf{H}$ - distal end of spicule; $\mathbf{I}$ - egg; $\mathbf{J}, \mathbf{K}$ - caudal end of male, lateral and ventral views; $\mathbf{L}$ - region of vulva; $\mathbf{M}$ - tail of female, lateral view; $\mathbf{N}$ - tip of female tail. Scale bars in $\mathrm{mm}$. 


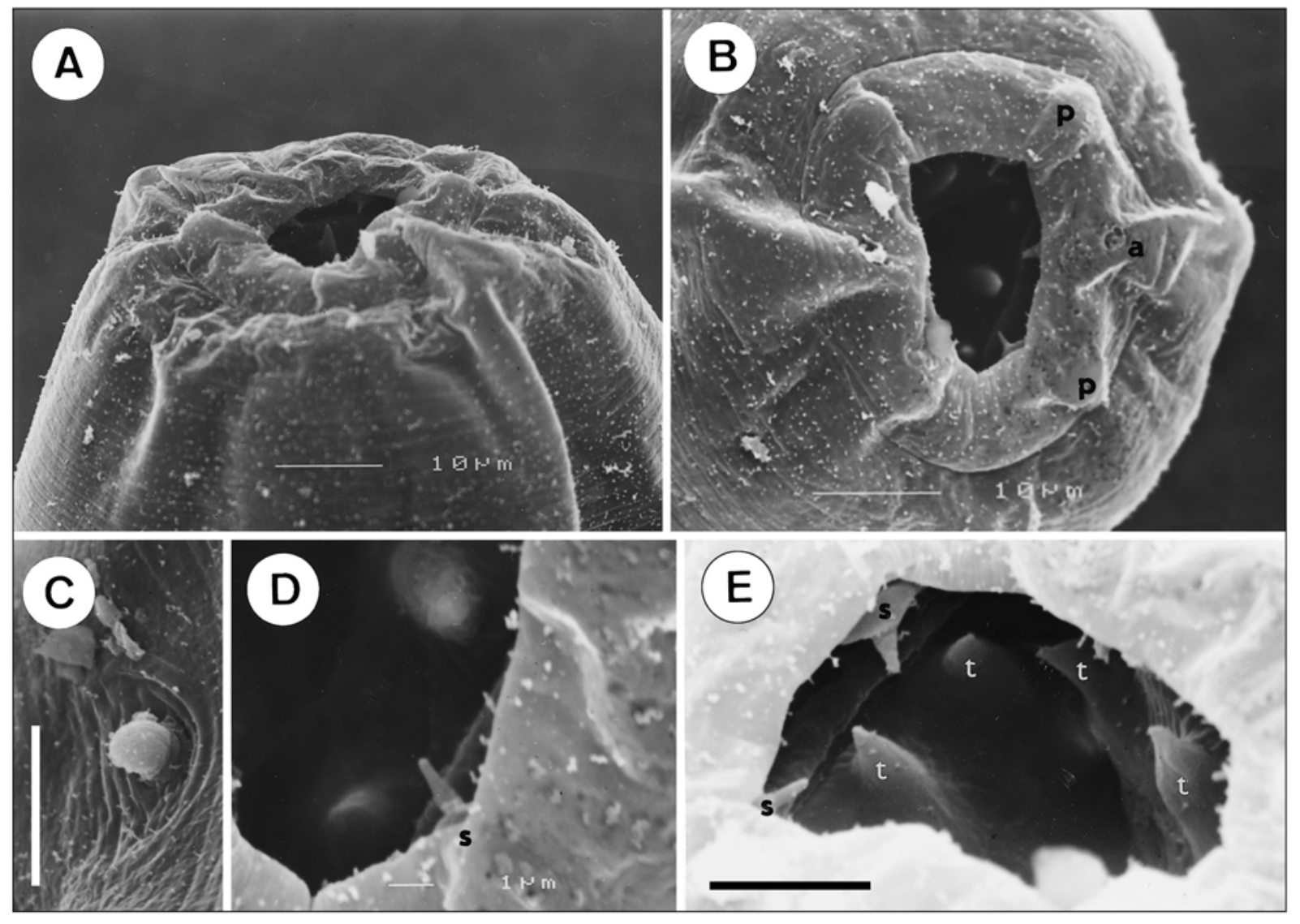

Fig. 2. Paraseuratoides ophisterni gen. et sp. n., scanning electron micrographs of anterior end of female. A, B - cephalic end, sublateral and apical views; $\mathbf{C}$ - deirid (scale bar $=10 \mu \mathrm{m}$ ); $\mathbf{D}$-detail of subventral part of oral opening with distinct spine; $\mathbf{E}$ - oesophageal teeth and oral spikes in buccal cavity (scale bar $=5 \mu \mathrm{m})$. a-amphid; $\mathrm{p}$-cephalic papilla; $\mathrm{s}-$ oral spike; $\mathrm{t}$ - oesophageal tooth.

large intestinal caecum, represents the subfamily Omeiinae Sobolev, 1949, whereas all other genera are listed in the Quimperiinae Gendre, 1928. In contrast to Chabaud (1978), Moravec (1994) considered Ichthyobronema Gnedina et Savina, 1930 a valid genus in Quimperiinae. Within this subfamily, Baker et al. (1987) established Desmognathinema and Hasegawa (1988) Wakubitinema for amphibian parasites, but the latter was synonymised with the former by Moravec and Sey (1990). Two more genera in this subfamily, Neoquimperia Wang, Zhao, Wang et Zhang, 1979 and Wuinema $\mathrm{Yu}$ et Wang, 1992 were erected for fish parasites in China (Wang et al. 1979, Yu and Wang 1992), but it is evident that the former is a junior synonym of Ezonema Boyce, 1971 and the latter a synonym of Paragendria Baylis, 1939. An additional genus, Neoparaseuratum Moravec, Kohn et Fernandes, 1992, was established for the species parasitising SouthAmerican freshwater fishes (Moravec et al. 1992). Consequently, at present the Quimperiinae includes 14 valid genera.
Of them, only species of Paraseuratum Johnston et Mawson, 1940, Desmognathinema Baker, Goater et Esch, 1987, and Neoparaseuratum have either no lateral alae or a precloacal sucker in the male. However, in contrast to Paraseuratoides gen. n., Desmognathinema has the oesophagus distinctly separated into muscular and glandular portions, whereas Neoparaseuratum is characterised by the cephalic region surrounded by numerous longitudinal bands of inflated cuticle.

Thus, the morphology of Paraseuratoides seems to be most similar to that of Paraseuratum; however, the former differs from the latter mainly in having no bulbous inflation on the anterior end of the oesophagus and in the structure of the mouth (presence of six spines in addition to six oesophageal teeth). Moreover, the type species of Paraseuratum, $P$. tandani Johnston et Mawson, 1940, a parasite of catfishes in Australia, is reported to possess narrow caudal alae in the male, which have not been observed in the two congeneric South-American species (Kloss 1966, Fábio 1982, Petter 1987); since P. tandani is inadequately described, 
the appurtenance of South-American species to this genus is not sure according to Petter (1987). An unpaired preanal papilla and ventral precloacal oblique muscle bands, well developed in the type species of Paraseuratoides, are absent in Paraseuratum spp.

Paraseuratoides ophisterni is the first quimperiid nematode reported from Mexico and the fourth one in North America, from where Haplonema immutatum Ward et Magath, 1917, Ichthyobronema conoura Gnedina et Savina, 1930 (syn. Haplonema hamulatum Moulton, 1931) and Desmognathinema nanthalaensis Baker, Goater et Esch, 1987 have previously been reported from fishes and amphibians in Canada and the USA. In South America, quimperiid nematodes are represented by a few species of the genera Paraseuratum, Touzeta Petter, 1987 and Neoparaseuratum in freshwater fishes (Moravec 1998).

Family P hil o m e tri d a e Baylis et Daubney, 1926

\section{Philometra ophisterni sp. n.}

Figs. 3, 4

Gravid female (based on 3 complete and 3 incomplete specimens; measurement of holotype in parentheses): Body of specimens containing larvae filiform, whitish, almost cylindrical, 28.67-39.30 (39.30) long, maximum width $0.381-0.625$ (0.625). Cuticle thin, smooth; only in some specimens examined by SEM, a few small transverse areas of elevated cuticle were observed (not visible in light microscope). Cephalic end rounded, cephalic papillae small, almost indistinct in lateral view. Oral aperture almost circular (slightly triangular), with three lobular sectors of oesophagus of which dorsal one bears distinct small sclerotised tooth. Oral aperture surrounded by two lateral amphids and minute submedian cephalic papillae arranged in two circlets; inner circlet formed by four single papillae, outer circlet by eight papillae arranged in four pairs; paired papillae rather far from each other. Anterior end of oesophagus forming conspicuous, strongly muscular spherical bulb, well separated from cylindrical portion of oesophagus; bulb 0.087-0.114 (0.114) long and $0.096-0.138(0.138)$ wide. Greater, posterior portion of oesophagus cylindrical, with prominent dorsal oesophageal gland extending anteriorly well anterior to level of nerve ring and posteriorly to small ventriculus measuring 0.021-0.030 × 0.030-0.036 $(0.021 \times 0.030)$. Entire oesophagus 1.265-1.700 (1.700) long, 0.1170.150 (0.150) wide, representing 4.0-5.5\% (4.3\%) of body length; length of gland 1.197-1.555 (1.555), maximum width $0.099-0.120 \quad(0.120)$; oesophageal gland provided with relatively small nucleus located at about mid-level. Oesophageal valve well developed. Nerve ring 0.219-0.261 (0.240) from anterior extremity. Intestine narrow, dark brown, straight, with its posterior end atrophied, forming thin ligament 0.015-0.024 (0.015) long, attached ventrally to body wall near posterior extremity. Posterior end of body rounded, bearing two inconspicuous, papilla-like lateral (almost terminal) projections 0.006-0.009 (0.006) high; distance between projections in lateral view 0.039 (0.039). Vagina and vulva absent. Anterior ovary reaching anteriorly up to level of nerve ring; posterior ovary not reaching posteriorly to level of intestinal ligament. Uterus occupying most space in body, extending anteriorly to oesophagus region and posteriorly not reaching to level of ligament; uterus filled with numerous larvae. Body of first-stage larvae slender, 0.5610.594 (0.561-0.594) long, maximum width 0.018-0.021 (0.018-0.021); oesophagus $0.159-0.171(0.159-0.171)$ long; sharply pointed tail $0.120-0.150(0.120-0.150)$ long, forming $21-23 \%$ (21-23\%) of body length.

Subgravid female (based on 2 specimens): Body elongate, whitish, with smooth cuticle. Body of specimens with eggs in uterus 10.06-22.02, maximum width 0.204-0.354. Cephalic end rounded. Oral opening surrounded by minute cephalic papillae. Anterior end of oesophagus forming conspicuous spheroid bulb, separated from cylindrical portion of oesophagus; bulb 0.075-0.090 long and 0.075-0.114 wide. Entire oesophagus 0.993-1.265 long, 0.048-0.078 wide, representing $5.7-9.9 \%$ of body length. Ventriculus $0.024 \times 0.030-$ 0.033 ; oesophageal gland $0.680-1.115$ long and 0.030 0.042 wide. Nerve ring 0.192-0.222 from anterior extremity. Excretory pore visible in smallest specimen at 0.653 and oesophageal nucleus at 0.694 from anterior end of body. Intestinal ligament 0.015 long. Posterior end of body rounded, provided with two subterminal papilla-like projections $0.009-0.015$ high. Vagina and vulva absent. Ovaries tubular, reflected, situated near body ends. Uterus containing numerous, almost spherical eggs 0.021-0.030 in diameter.

Male: Unknown.

T y p e h o s t : Swamp-eel, Ophisternon aenigmaticum Rosen et Greenwood, 1976 (total body length 26-54 cm).

$\mathrm{S}$ i t e : Mesentery in region of heart.

$\mathrm{T}$ y p e 1 o c a 1 i t y : Canal of the Papaloapan River at Tlacotalpan (18³6’ N, 95³9'W), Veracruz, Mexico (collecting dates: 30 April and 1 May 2001).

Prevalence and intensity : 56\% (5 fish infected/ 9 fish examined), 1-5 (mean 3) nematodes per fish.

De p o s ition of speci men s: Holotype and paratypes in the Institute of Biology, UNAM, in Mexico City (Cat. Nos. CNHE 4293 and 4294); paratypes in the Institute of Parasitology, ASCR, in České Budějovice (Cat. No. N-781).

Comments: The family Philometridae Baylis et Daubney, 1926 includes a large number of species parasitic mainly in the abdominal cavity and various body tissues of freshwater and marine fishes. Since minute males of many species and genera are unknown, the present classification in this difficult group of nematode parasites is principally based on the female morphology (Rasheed 1963, Ivashkin et al. 1971, Chabaud 1975, Moravec and Shaharom-Harrison 1989). 

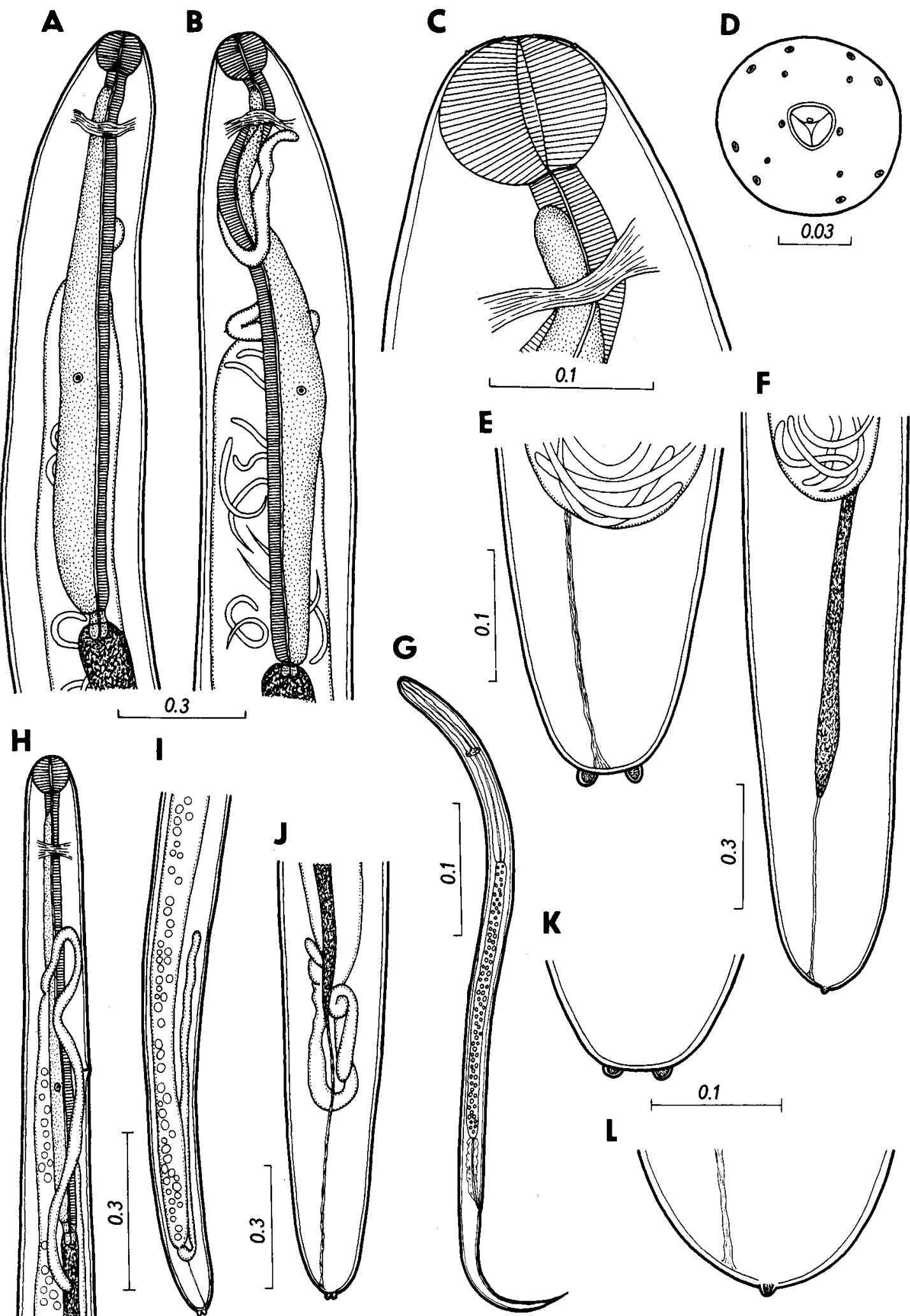

Fig. 3. Philometra ophisterni sp. n., female. A - anterior end of gravid specimen; B - same, another specimen; C, D - cephalic end of gravid specimen, lateral and apical views; E, F - posterior end of gravid specimen, dorsoventral and lateral views; $\mathbf{G}-$ larva from uterus; H, I - anterior and posterior ends of smallest subgravid female; J - posterior end of larger subgravid specimen; K, $\mathbf{L}$ - caudal end of gravid specimen, dorsoventral and lateral views. Scale bars in $\mathrm{mm}$. 


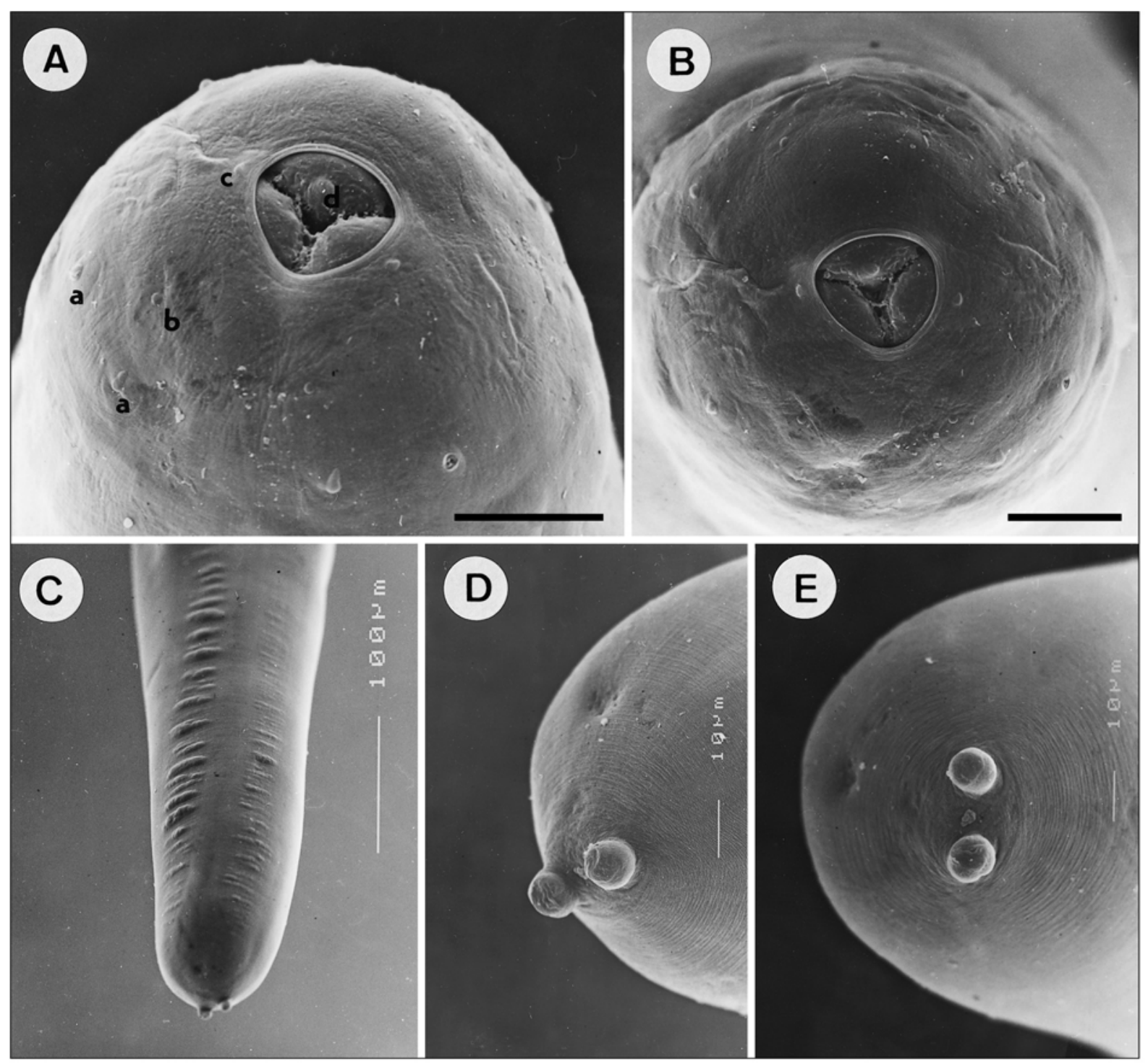

Fig. 4. Philometra ophisterni sp. n., scanning electron micrographs of gravid female. A, B - cephalic end, sublateral and apical views (two different specimens) (scale bars $=20 \mu \mathrm{m}$ ); $\mathbf{C}$ - posterior end of body of specimen with areas of elevated cuticle; $\mathbf{D}, \mathbf{E}$ - caudal end, sublateral and apical views. a - cephalic papilla of external circle; b-cephalic papilla of inner circle; c-amphid.

In addition to morphological features, data on the site of localisation of gravid females in the host's body are also important for the identification of philometrids (Moravec and Rohde 1992).

Of many species of Philometra Costa, 1845, gravid females of the following 13 species possess an anterior oesophageal bulb and two distinct caudal projections, and are parasitic in the abdominal cavity or some internal organs: $P$. abdominalis Nybelin, 1928, $P$. biglobocerca Belous, 1965, P. coreii Yu et Wang, 1997, P. cylindracea (Ward et Magath, 1916), P. gobioboti Yi et Guitang, 1997, P. hyderabadensis Rasheed, 1963, P. karunensis Pazooki et Molnár, 1998, P. kotlani (Molnár, 1969), P. obturans (Prenant, 1886), P. ovata (Zeder,
1803), P. parasiluri Yamaguti, 1935, P. polynemii Rasheed, 1963, and P. salgadoi Vidal-Martínez, Aguirre-Macedo et Moravec, 1995.

Except for $P$. parasiluri and $P$. salgadoi reported from the host's orbit and $P$. hyderabadensis and $P$. obturans parasitic in the blood system, all these species were described from the abdominal cavity of their fish hosts; most of them are parasites of freshwater fishes, whereas P. biglobocerca, $P$. polynemii and P. salgadoi are known from brackish-water and marine fishes (Epinephelus, Mugil, Polynemus).

In contrast to $P$. ophisterni, in none of the above mentioned species the anterior oesophageal bulb is so much developed and separated from the cylindrical part 
of the oesophagus; only the anterior bulb of $P$. coreii may somewhat resemble that in P. ophisterni (see Yu and Wang 1997), but the cephalic end of this species is truncated (vs. rounded), the caudal projections are smaller, not exceeding the posterior end of the body, and the body length of the gravid female is approximately double as compared to that of $P$. ophisterni.

The extent of the oesophageal gland of $P$. ophisterni is almost unique among all Philometra species. Besides P. ophisterni, there are only two other Philometra species, $P$. parasiluri and $P$. coreii, in which the oesophageal gland opens anteriorly to the level of the nerve ring (Yamaguti 1935, Yu and Wang 1997). Philometra parasiluri can be easily distinguished from $P$. ophisterni by the presence of eight large cephalic papillae. Both $P$. coreii and $P$. parasiluri are parasitic in freshwater fishes in East Asia (China, Japan).

The 13 above mentioned Philometra species with two distinct caudal projections differ from $P$. ophisterni also in other morphological features: the caudal projections of $P$. abdominalis, $P$. cylindracea, $P$. gobioboti, $P$. karunensis, $P$. kotlani, $P$. obturans and $P$. polynemii are smaller, located distinctly laterally, far from each other, and not exceeding posteriorly the posterior end of the body. The caudal projections of $P$. biglobocerca are lateral, much larger $(0.16 \mathrm{~mm}$ in diameter $)$, and also cephalic papillae are marked. The caudal projections of $P$. hyderabadensis and $P$. salgadoi are much smaller, submedian, situated close to each other. The cephalic papillae of $P$. polynemii and $P$. salgadoi are conspicuously large. There are also marked differences in the body length of the gravid female in some species.
Philometra ophisterni differs from all related congeners also in the geographical distribution and the host type. Most of these species occur in Europe and Asia, the only American species being $P$. cylindracea from the abdominal cavity of the freshwater fish, Perca flavescens (Mitchill), in Canada and the USA (Ashmead and Crites 1975, Molnár and Fernando 1975) and $P$. salgadoi from the orbits of the marine fish, Epinephelus morio (Valenciennes) from the southern Gulf of Mexico (Vidal-Martínez et al. 1995, Moravec et al. 2001); no species of this morphological group of Philometra has so far been recorded from freshwater fishes of the Neotropical Region (Moravec 1998).

Philometra ophisterni represents the first species of this genus recorded from an inland fish in Mexico and the first philometrid nematode parasitising a host species of the order Synbranchiformes.

Acknowledgements. The authors' thanks are due to Guillermina Cabañas-Carranza, Petra Sánchez-Nava and Raphael Báez-Valé from the Instituto de Biología, UNAM, Mexico City for their help in the field, to the staff of the Laboratory of Electron Microscopy of the Institute of Parasitology, ASCR, in České Budějovice, for their technical assistance, and to Irena Husáková of the same Institute for her help with the illustrations. A part of the work was done during F. Moravec's short stay in the Instituto de Biología, UNAM, with support of the Consejo Nacional para la Ciencia y la Tecnología (CONACyT), Mexico. This study was supported by the grant No. 400355-5-27668N from the Consejo Nacional para la Ciencia y la Tecnología (CONACyT) and by the grant No. A60222901 from the Grant Agency of the Academy of Sciences of the Czech Republic.

\section{REFERENCES}

ASHMEAD R.R., CRITES J.L. 1975: A description of the male and redescription of the female of Philometra cylindracea Ward and Magath, 1916 [sic] (Nematoda: Philometridae). Proc. Helminthol. Soc. Wash. 42: 143145.

BAKER M.R., GOATER T.M., ESCH G.W. 1987: Descriptions of three nematode parasites of salamanders (Plethodontidae: Desmognathinae) from the southeastern United States. Proc. Helminthol. Soc. Wash. 54: 15-23.

CHABAUD A.G. 1975: Keys to Genera of the Order Spirurida. Part 1. Camallanoidea, Dracunculoidea, Gnathostomatoidea, Physalopteroidea, Rictularioidea and Thelazioidea. In: R.C. Anderson, A.G. Chabaud and S. Willmott (Eds.), CIH Keys to the Nematode Parasites of Vertebrates. No. 3. Commonwealth Bureaux, Farnham Royal, Bucks (UK), 27 pp.

CHABAUD A.G. 1978: Keys to Genera of the Superfamilies Cosmocercoidea, Seuratoidea, Heterakoidea and Subuluroidea. In: R.C. Anderson, A.G. Chabaud and S. Willmott (Eds.), CIH Keys to the Nematode Parasites of Vertebrates. No. 6. Commonwealth Bureaux, Farnham Royal, Bucks (UK), 71 pp.
ESPINOSA-PÉREZ H., GASPAR-DILLANES M.T., FUENTES-MATA P. 1993: Listados Faunísticos de México. III. Los Peces Dulceacuícolas Mexicanos. Instituto de Biología, UNAM, México, 99 pp.

FÁBIO S.P. 1982: Sobre alguns Nematoda parasitos de Hoplias malabaricus. Arq. Univ. Fed. Rur. Rio de J. 5: 179-186 + 15 Figs.

HASEGAWA H. 1988: Wakubitinema toyamai n. gen. and n. sp. (Nematoda: Seuratoidea: Quimperiidae) from the intestine of Rana (Limnonectes) namiyei (Amphibia: Ranidae) on Okinawa Island, Jpn. J. Parasitol. 74: 332335.

IVASHKIN V.M., SOBOLEV A.A., KHROMOVA L.A. 1971: Camallanata of Animals and Man and the Diseases Caused by Them. Osnovy Nematodologii 22. Nauka, Moscow, 388 pp. (In Russian.)

KLOSS R. 1966: Helmintos parasitos de espécies simpátricas de Astyanax (Pisces, Characidae). 1. Pap. Avulsos Dep. Zool. (São Paulo) 18: 189-219.

MOLNÁR K., FERNANDO C.H. 1975: Morphology and development of Philometra cylindracea (Ward and Magath, 1916) (Nematoda: Philometridae). J. Helminthol. 49: $19-24$ 
MORAVEC F. 1994: Parasitic Nematodes of Freshwater Fishes of Europe. Academia and Kluwer Academic Publishers, Praha and Dordrecht, Boston, London, 473 pp.

MORAVEC F. 1998: Nematodes of Freshwater Fishes of the Neotropical Region. Academia, Praha, 464 pp.

MORAVEC F., KOHN A., FERNANDES B.M.M. 1992: Neoparaseuratum travassosi n. g., n. sp. (Nematoda: Quimperiidae), a new parasite from thorny catfish Pterodoras granulosus in Brazil. Mem. Inst. Oswaldo Cruz 87 (Suppl. 1): 145-150.

MORAVEC F., ROHDE K. 1992: Three species of nematodes of the superfamily Dracunculoidea from Australian fishes. Acta Soc. Zool. Bohemoslov. 56: 187-195.

MORAVEC F., SALGADO-MALDONADO G., JIMÉNEZGARCÍA I. 2000: Pseudocapillaria (Ichthyocapillaria) ophisterni sp. n. (Nematoda: Capillariidae) from the swamp-eel Ophisternon aenigmaticum (Pisces) in Mexico. Parasitol. Res. 86: 290-293.

MORAVEC F., SEY O. 1990: Some nematode parasites of frogs from Papua New Guinea and Australia. Acta Soc. Zool. Bohemoslov. 54: 268-286.

MORAVEC F., SHAHAROM-HARRISON F. 1989: Paraphilometroides nemipteri gen. et sp. n. (Nematoda: Philometridae) from the marine fish Nemipterus peronii (Valenciennes) from Malaysia. Folia Parasitol. 36: 345350 .

MORAVEC F., VIDAL-MARTÍNEZ V.M., AGUIRREMACEDO M.L., GONZÁLEZ-SOLÍS D. 2001: First description of the male and redescription of the female of Philometra salgadoi Vidal-Martínez et al., 1995 (Nematoda: Philometridae) from the ocular cavity of the marine fish Epinephelus morio in Mexico. Parasitol. Res. 87: 526-529.

PETTER A.-J. 1987: Nématodes de Poissons de l'Equateur. Rev. Suisse Zool. 94: 61-76.
RASHEED S. 1963: A revision of the genus Philometra Costa, 1845. J. Helminthol. 37: 89-130.

SCHOLZ T., AGUIRRE-MACEDO M.L., SALGADOMALDONADO G. 2001a: Trematodes of the family Heterophyidae (Digenea) in Mexico: a review of species and new host and geographical records. J. Nat. Hist. (In press.)

SCHOLZ T., de CHAMBRIER A., SALGADOMALDONADO G. 2001b: Monticellia ophisterni n. sp. (Cestoda: Monticelliidae) from the swamp-eel Ophisternon aenigmaticum (Synbranchiformes) from Mexico. J. Parasitol. 87: 1328-1333.

VIDAL-MARTÍNEZ V.M., AGUIRRE-MACEDO M.L., MORAVEC F. 1995: Philometra (Ranjhinema) salgadoi n. sp. (Nematoda: Philometridae) from the ocular cavity of the red grouper Epinephelus morio (Pisces: Serranidae) from the Yucatan Peninsula, Mexico. J. Parasitol. 81: 763766.

WANG P.-Q., ZHAO Y.-R., WANG X.-Y., ZHANG J.-V. 1979: Report on some nematodes from vertebrate animals in Central and South China. Fujian Shida Xuebao 2: 7892. (In Chinese, Engl. summary.)

YAMAGUTI S. 1935: Studies on the helminth fauna of Japan. Part 9. I. Nematodes of fishes. Jpn. J. Zool. 6: 337-386.

YU Y., WANG G.-T. 1992: Studies on fish parasitic nematodes of Wuinema gen. nov. and W. mysti sp. nov. Acta Hydrobiol. Sin. 16: 299-303. (In Chinese, Engl. summary.)

YU Y., WANG G.-T. 1997: Notes on the nematodes, including several new species, from fishes from Wuling Mountains area. In: Song Daxiang (Ed.), Invertebrates of Wuling Mountains Area, Southwestern China. Science Press, Beijing, pp. 240-252. (In Chinese, Engl. summary.)

Accepted 6 September 2001 